\title{
Corruption and Bribery in the Eyes of Public Opinion
}

\author{
Miroslav Scheinost \\ Institute of Criminology and Social Prevention, Czech Republic
}

Copyright $\mathrm{C} 2016$ by authors, all rights reserved. Authors agree that this article remains permanently open access under the terms of the Creative Commons Attribution License 4.0 International License

\begin{abstract}
The article reflects the perception of corruption during the last several years. Within this period corruption has become the focus of the media attention and it has even become one of the important words of the vocabularies of politicians. Czech general public has been quite skeptical in terms of the state of the corruption of our society and believes that the incidence of corruption is significant. It is of course necessary to differentiate the feelings and fears of public from the limited factual knowledge on its phenomenon itself. Because of the lack of hard data on corruption the exploration is therefore based on the secondary analysis of findings from surveys on public opinion carried out in the Czech Republic and on the analysis of Czech governmental strategic documents concerning this phenomenon. Author takes into account mostly the views on corruption in public sector. It tries to answer the question whether the situation can be characterized as "common" corruptive behavior on the everyday level, as "corruptive climate" or even as systemic corruption steering for the so-called "state capture". It tries also to formulate the main differences of the extent and character of corruption under socialist period and at present.
\end{abstract}

Keywords Corruption, Public Opinion, Differences between Socialist and Present Period

\section{Introduction}

During the last several years the corruption became a very frequent term in the Czech Republic, not only as a subject of conversations of citizens. It has become the focus of the media attention and it has even become one of the important words of the vocabularies of politicians that even stressed the fight against corruption as a one of the pillars of governmental programs. We can, however, guess at whether the politicians really wanted to reflect the extent of this phenomenon in society, or whether it was again only one of the means of "captatio benevolentiae" of the public. But what has been meant by "corruption"? Is the meaning of this word the same one in the language of people and in the language of politicians?
Obviously, the term corruption is in common use and even in the political language quite vague and includes many different connotations, meanings and activities. And, moreover, the burden of corruption is perceived by the different way - what is a clear bribe for somebody may be only "a tiny expression of attention" for somebody else.

That is why the topic of this analysis is not the criminological or legal definition of corruption but perception of corruption in the eyes of public as shown on the Czech example. It is obvious that the public tends to understand the term "corruption" not according the wording of law but rather intuitively, more by feeling than by strict specification of concept. Therefore we of course cannot base the description of the real extent and shape of corruption only on the views and opinion of public. But we may better understand what behavior is translated by public to be corruptive and in what sectors of public life people feel the strongest corruption. And this public opinion must be taken into account as one of powerful factors of corruptive climate in the society. If we analyze the corruption from this point of view we may also ask where the roots of the concept of corruption as seen by public might be found.

\section{Materials and Methods}

The study is methodologically based on the secondary analysis of researches and inquiries carried out in the Czech Republic within the period since 2010 and on the relevant data of institutions as e.g. Transparency International. These inquiries were carried out on using either the representative samples of public or samples of concrete groups of respondents (entrepreneurs).

Only for complement we may briefly mention the penal recourse of corruption and the official numbers. The Czech criminal law is quite strict against the corruption. An offense of bribery is under sentence of imprisonment for up to four years, but if there are aggravating circumstances the punishment may substantially rise with the maximum limit relating to acts committed with the intention of procuring large-scale benefit for themselves or someone else, or committed such an act as an official person with the intention of procuring a substantial benefit for themselves or another person even for up to twelve years. [1] 


\section{Results}

But should we only make judgments by the number of accused offenders, we would have to say that the extent of corruption is almost negligible. As an illustration we can display the following table with the number of persons accused for the bribery [1]:

Table 1. Number of accused persons for bribery by the Czech Penal Code

\begin{tabular}{|c|c|c|}
\hline YEAR & Bribe-taking & Bribe-giving \\
\hline 2005 & 91 & 82 \\
\hline 2006 & 40 & 96 \\
\hline 2007 & 37 & 65 \\
\hline 2008 & 42 & 65 \\
\hline 2009 & 31 & 68 \\
\hline 2010 & 31 & 82 \\
\hline 2011 & 50 & 164 \\
\hline 2012 & 85 & 108 \\
\hline 2013 & 33 & 96 \\
\hline 2014 & 24 & 170 \\
\hline
\end{tabular}

Source: Yearbooks of Criminality [2]

Back to the public opinion: in contrast to the official statistics Czech general public has been quite skeptical in terms of the state of the corruption in our society and believes that the incidence of corruption is significant as show the results of various surveys of public opinion on corruption and the corruption climate.

If we mention the well-known Corruption Perception Index CPI, regularly produced by Transparency International, then in 2010 the Czech Republic was classified 4.6 (on a scale from 0 to 10 , where 10 indicates a country with almost no corruption and 0 means a high level of corruption) and ranked the 53-rd. in the chart covering 178 countries.[3] Global Barometer of Corruption, organized also by Transparency International and carried out in 2013 on the global sample of more than 114000 respondents showed that $83 \%$ of the Czech respondents consider the corruption in public sector to be serious or very serious problem.

Research conducted in our Institute of Criminology and Social Prevention in 2010 on a representative sample of 977 respondents focused on the views and experiences of people regarding the corruption in relation to the public administration. For the purpose of this survey we defined corruption as a relationship between a corrupting person and a corrupt person when a corrupting person offers, and usually provides some form of remuneration for being granted an undue advantage; a corrupt person provides or promises such an advantage and expects or requires a reward for this.

The research showed that about one third of respondents say they know someone who was forced to give a bribe to an official. This argument, however, has to be confronted with only $13 \%$ of respondents saying that during the last three years they got into a situation when someone directly or indirectly required a bribe from them. The opinion as to who is the initiator of corruption has been interesting: $24 \%$ of respondents said that the initiative comes mostly from official, $29 \%$ considers level of activity of citizens and officials in corrupt conduct roughly the same, $18 \%$ believe that the activity is mostly on the part of citizens and $29 \%$ do not know. $46 \%$ of respondents believe that the official usually accepts an offered bribe.

Thus, the public opinion on corruption, respectively the corruption resistance of officials is not very favorable. In this situation, a rather positive - although this statement is to be taken critically - is the statement that $40 \%$ of the respondents claim that they never offered a bribe and never gave any.

In this survey we asked why people give bribes to officials. The results are interesting because they show what people consider to be incentives of corruptive behavior. The order of these reasons by weight attributed to them by respondents has been as follows:

Table 2. The weight attributed by respondents to incentives of corruptive behavior

\begin{tabular}{|c|c|}
\hline They consider it a courtesy to the official & $\mathbf{2 . 8 5}$ \\
\hline An official directly requires this from them & $\mathbf{2 . 5 7}$ \\
\hline They want to thank the official for taking care of it & $\mathbf{2 , 4 8}$ \\
\hline The official indicated this to them & $\mathbf{2 . 2 5}$ \\
\hline They believe there is no other way & $\mathbf{2 . 2 5}$ \\
\hline Someone has indirectly said them they should give a bribe & $\mathbf{2 . 1 6}$ \\
\hline They want to force an official to act in their interest & $\mathbf{2 . 1 1}$ \\
\hline They want to influence the official to act in their interest & $\mathbf{1 . 9 6}$ \\
\hline
\end{tabular}

Source: Research results of ICSP 2010

These statements indicate a rather considerable degree of tolerance towards corruption, or its acceptance as the view that a bribe to an officer is an expression of grace, gratitude and necessity, prevails. This corresponds to a statement as to what would a citizen do upon encountering a corruption. Only $26 \%$ would complain about the institution where this behavior took place or would notify the police (only 3\% within these $26 \%$ would be willing to testify in court). [4]

Czech public tends to consider public administration and politics to be areas most influenced by corruption. The presumption that corruption in public administration occurs especially in the management of public resources, such as public procurement, is confirmed by a survey on corruption among businessmen, which was in the beginning of 2010 implemented by Association of Small and Medium-Sized Enterprises and Tradesmen. [5] The question "Do you think it's possible to get a public contract in the Czech Republic without a commission or bribe?" was answered as follows: "definitely NOT" - 29.4\% respondents, "Somewhat NOT" $29.9 \%$ respondents. Thus, almost $60 \%$ of entrepreneurs believe that without a bribe any public contract can be obtained. Only $7.1 \%$ of respondents "strongly" believe that 
public procurement can be obtained free of corruption, and $23.3 \%$ "somewhat" believe that it is possible.

In 2009, the largest part of the population of the Czech Republic identified political parties as the area with the highest incidence of corruption (22\%). Authorities were the second most corruption-ridden area in the Czech Republic according to the Czech citizens (17\%). More than one in ten people appointed by the Ministries (14\%) and a tenth of the respondents identified the government as the fourth most corrupt area. People associated the corruption the least often with education, customs officers, the voluntary sector, churches and banking and also the media. [6]

According the results of Global Barometer of Corruption in 2013 these results were rather confirmed. As extremely corrupted were identified political parties $(38 \%)$, state officials (37\%), Parliament (28\%) and judiciary (21\% of respondents). Very small incidence of corruption was identified with regard to NGO's, charity, churches and media.

These findings are supported by the results of research carried out in 2011.[7] More people are starting to consider corruption to be organized (almost $50 \%$ ), or even a system (over 20\% in 2011), and ever less people consider it to be just occasional.

There is a strong correlation between the understanding of corruption as a systemic and organized and the critical attitude to the current political system. It can be to some extent attributed to high levels of general disgust with the state of politics and the behavior of politicians. It can also be documented by a representative periodic study of competitiveness published by the World Economic Forum [8]. The study assesses the country according to many different criteria. While within the overall competitiveness ranking the Czech Republic was classified relatively well for the 2010-2011 period (36-th place in the world out of 139 surveyed countries), it placed 72 in terms of the quality of government institutions. It is worth noting sub-criterion of "public trust in politicians", where the Czech Republic ranked 121 (out of 139!).

The above researches suggest how to explain the apparent contradiction between the generally shared views on corruption-ridden country and the relatively limited amount of persons who really got in contact with corruption (as providers or recipients of bribes). According to the research "Actor 2011" approximately $60 \%$ of people is not involved in corruption neither as providers nor recipients. [7] In Global Barometer of Corruption only $15 \%$ of respondents stated that they gave a bribe within last year. The explanation may be that the critical attitude of public towards the corruption in the Czech Republic is targeted on the state administration area, distribution of public funds, the chaotic intertwining of the interests of political parties, government and business. The main problem of corruption is not primarily identified as individual corruption in the provision of various sub-services, but the systemic manipulation with public resources, and this is also how the corruption is particularly critically perceived. Citizens consider the big, politically conditioned corruption more serious, while areas dominated by the so-called minor, administrative corruption are not considered to be as serious [9]. This interpretation is supported by the finding that within people that admitted giving the bribe within the last year $57 \%$ stated that it was only some gift as a consecutive expression of gratitude.

This confirms the conclusion that the problem of corruption in the Czech Republic is perceived by public as the system corruption, the organized abuse of public resources, with links to the political structure rather than in a "petty corruption". Briefly, the public perceive the corruption in the Czech Republic as so-called "state capture". [10]

\section{Discussion}

If we try to compare the appearance of corruption during the Communist regime with the current situation, we would obviously find significant differences. Under the communist regime, there was an apparent "minor" corruption at the level of everyday life, based largely on the "networks of mutual favors", consisting of the mutual provision and procurement of scarce goods and services. However, these networks disqualified those, who had nothing to offer. At a higher level clientelism operated, which was primarily motivated by an effort to obtain and secure a good position within the power system and not primarily economic gain, which resulted from the then political-economic arrangements.

The transformation has brought a transformation of corruption. "Small" corruption at the level of everyday life has subsided to some degree, as both common and luxury goods and services are now available without much difficulty; the amount of the client's money is the only limit. The importance of this type of corruption therefore has also decreased in the eyes of the public. What has significantly changed is the corruption at higher level, mainly because it began to be motivated first and foremost by an economic benefit. In the initial phase of the transformation process the access to resources, to the privatized property and to the information in order to gain advantage at the expense of potential competitors was the primary thing. Bribery was associated with possibilities of obtaining credits, without which starting a business at the newly opened and the created market would be hardly conceivable. The corrupt behavior was undoubtedly strengthened by a policy-driven effort to speed up the transition process disregarding the deficiencies and gaps in its legal regulation. In the next phase, the struggle for state and public procurement came, which still represent a huge source of revenues and profit plus the effort to get subsidies from European and other funds? Corrupt behavior focuses on circumvention of mandatory rules and procedures. The object of corruption pressure is not only government officials but also politicians from local through regional to central level. The opinion that the level of corruption in this sector is critical and achieves the aforementioned "state capture", is pronounced in public 
opinion surveys very distinctly.

\section{Conclusions}

We cannot simply say that it is a true picture of corruption in our country. In any case, however, we must take it as an important source of information because there is a double-end process: manifestations and forms of corruption influence its image in the eyes of public and this image substantially influences the real behavior of people in corruptive situation. It seems to be clear that Czech public is rather tolerant against so called "minor corruption" that takes place in the frame of interpersonal relations at a level of everyday life. This tolerance is probably inherited from the period of socialism when this behavior was the stable part of life and took the shape of the mutual exchange based on possibilities that had the both sides of relation at disposal. But in the same time the Czech public is very critical toward the "big corruption" that is believed to be rooted in the economic and political life. As we stated it is not possible to conclude only on the basis of public opinion that the political and economic processes have been so strongly influenced by systemic corruption. Nevertheless, the result of this prevailing public meaning is the decreasing trust into the politician and entrepreneurial sector and growing popularity of new political parties and movements that seem not to be burdened by this systemic corruption and by other sins of the past. The door for different populist parties and movements could be at least partly opened.

\section{REFERENCES}

[1] Czech Penal Code, 40/2009 Coll., Section 331 and 332
[2] Yearbooks of Criminality, Czech Ministry of Justice, 2006-2015

[3] http://www.transparency.org/policy_research/surveys_indice s/cpi/2010/results.

[4] M. Cejp. Od obecného pojetí k některým dílčím poznatkům $\mathrm{z}$ výzkumu veřejného mínění o korupci ve státní správě (From general concept to some partial knowledge on the corruption in state administration). Trestněprávní revue (Penal Law Review), Vol. 2011, No. 9, 256-260

[5] http://www.amsp.cz/uploads/soubory/pruzkum4_web_final.p df

[6] Mravec,M., Korupční klima v ČR (Corruptive Climate in the (CR), http://www.transparency.cz/doc/projekty/NIS/Konference/M artin_Mravec_GfK_Korupcni_klima_v_Ceske_republice.pdf

[7] Buriánek,J., Aktér 2011, European Social Survey, Round 5

[8] K. Schwab.:The Global Competitiveness Report 2011-2012. World Economic Forum, Geneva, 2011; http://www3.weforu m.org/docs/WEF_GlobalCompetitivenessReport_2010-11.p df

[9] R. Bureš. Korupce v České republice (Corruptiopnj in the CR). Kriminalistika (Criminalistics), Vol. 2012, No. 2, 105-121

[10] State capture" is a term used by the World bank, which is defined as "activities" of individuals, groups and companies, both in the public and private spheres aimed at influencing the creation of laws, regulations, decisions and other governmental procedures for their own benefit as a result of illegal and non-transparent provisions of the private nature to public authorities officers .... Thanks to informal, non-transparent and preferential channels. This also takes place through unclear alliances between political and business interests of public officials ..."(see B.Dančák, V.Hloušek, V.Šimíček. Korupce. Projevy a potírání v České republice a v Evropské unii (Corruption - Manifestations and Suppresion in the CR and in the European Union). Brno, 2006, 13 -15) 